\title{
Physical Map of the Genome of Vibrio cholerae 569B and Localization of Genetic Markers
}

\author{
RUMA MAJUMDER, SANGHAMITRA SENGUPTA, GOPAL KHETAWAT, RUPAK K. BHADRA, \\ SUSANTA ROYCHOUDHURY,* AND JYOTIRMOY DAS \\ Biophysics Division, Indian Institute of Chemical Biology, Calcutta 700 032, India
}

Received 27 July 1995/Accepted 4 December 1995

\begin{abstract}
A combined physical and genetic map of the genome of the classical O1 hypertoxinogenic strain 569B of Vibrio cholerae has been constructed. The enzymes NotI, SfiI and CeuI generated DNA fragments of suitable size distribution that could be resolved by pulsed-field gel electrophoresis. The digests produced 37, 22, and 7 fragments, respectively. The $\mathrm{CeuI}$ maps of the genomes of strains 569B and 0395 , constructed by partial restriction digestion, were identical, and the data are consistent with the concept of circular chromosomes. The genome size of each of the strains was estimated to be about 3.2 Mb. The NotI and SfiI digestion profiles of the genomic DNAs of strains 569B and 0395 exhibited distinct restriction fragment length polymorphism. The linkages between the 37 NotI fragments of the genome of strain 569B were determined by combining three approaches: isolation of linking clones, analysis of partial digestion fragments, and identification of NotI fragments in isolated $\mathrm{CeuI}$ and $S f i \mathrm{I}$ fragments. To align linked fragments precisely, NotI-digested genomic DNA was end labeled and separated in the same gel with the NotI-digested DNA to be probed with linking clones. This also allowed the identification of smaller restriction fragments that are not visible in ethidium bromidestained gels. The presence of repetitive DNA sequences in the $V$. cholerae 569B genome has been demonstrated. Twenty cloned homologous and heterologous genes and seven $r r n$ operons have been positioned on the physical map. The two copies of the Ctx genetic element in the genome of strain 569B are located about $1,000 \mathrm{~kb}$ apart.
\end{abstract}

Cholera still remains a public health problem in most developing countries. Vibrio cholerae, a noninvasive gram-negative bacterium and the causative agent of the disease, is serologically classified as belonging to the $\mathrm{O}$ antigenic group (38). Strains belonging to $\mathrm{O}$ group 1 (O1) are responsible for cholera. Strains other than O1 are called non-O1. Strains of serotype $\mathrm{O} 1$ consist of two biotypes, classical and El Tor. Of the seven pandemics of cholera recorded in recent times, the most recent was caused by $V$. cholerae $\mathrm{O} 1$ biotype El Tor (17). The sixth pandemic and probably the fifth (20) were due to classical strains. $V$. cholerae non-O1 strains can cause only sporadic infections and do not have the potential to cause epidemics (29). Only recently, an outbreak of cholera in India and Bangladesh which subsequently spread into several parts of the subcontinent was caused by a novel non-O1 strain, $V$. cholerae O139 Bengal $(1,33)$. However, several lines of evidence have suggested that strain O139 Bengal very closely resembles biotype El Tor of the O1 serovar $(6,43)$.

Although a great deal is known about the physiology, biochemistry, and clinical microbiology of $V$. cholerae (20), very little information is available about its chromosomal structure and its genetics. Only recently has transformation of $V$. cholerae cells by plasmid DNA been reported (30). Conjugation is mediated by a factor P (9), which unlike the F factor of Escherichia coli cannot integrate into the chromosome and cannot induce Hfr donors. Hence, the mobilization of chromosomal DNA is very limited. An expanded linkage map of the classical strain 162 in which not more than 30 loci have been mapped by conjugal transfer of Tfr donors has been reported (31). The relative distances between these markers are very approximate, and surprisingly, all the mapped genes are clustered in a limited region of the chromosome.

* Corresponding author. Phone: (91-33) 473 0350. Fax: (91-33) 473 0350/0284. Electronic mail address: iicb\%sirnetc@sirnetd ernet.in.
Knowledge of the genome structure is useful in exploring the complicated questions concerning global regulation of metabolisms such as genome rearrangement (18), control and rate of DNA replication-termination (22), and the dynamics and evolutionary aspects of genome organization (34). The alternative to examining the organization of genomes in organisms for which a genetic map is not available is to construct a physical map of the genome which represents the structure of the DNA. With the advent of pulsed-field gel electrophoresis (PFGE), which allows separation of large DNA fragments generated by digesting intact genomic DNA with rare restriction site enzymes, large physical restriction maps can now be assembled $(39,40)$. This technology has enabled accurate estimation of genome sizes, detection of gross chromosomal aberrations, and qualitative evaluation of intraspecies genetic variations which permit identification of individual isolates of a species by comparing the macrorestriction patterns.

The genome sizes of a number of $V$. cholerae strains have recently been determined by digesting the intact genomic DNA by the enzymes NotI and SfiI, which produce a small number of large fragments that could be resolved by PFGE ( 6 , $7,36)$. The genome sizes of all classical strains examined were about 3,200 kb, and surprisingly, those of strains of the El Tor biotype were 500 to $600 \mathrm{~kb}$ smaller. The NotI and SfiI digestion patterns of the genomes of $V$. cholerae strains belonging to different serovars and biotypes showed distinct restriction fragment length polymorphism (RFLP). The present report describes the construction of a physical map of the genome of the classical $\mathrm{O} 1$ hypertoxinogenic strain $569 \mathrm{~B}$ of $V$. cholerae using the enzymes CeuI and NotI and a partial SfiI map. Twenty homologous and heterologous genes and seven rrn operons have been placed on the physical map. The availability of physical restriction maps will allow us to address the issue of genetic heterogeneity among the $V$. cholerae strains belonging to different serovars and biotypes. 


\section{MATERIALS AND METHODS}

Bacterial strains and growth conditions. $V$. cholerae classical O1 strains 569B (Inaba) and O395 (Ogawa) used in this study were obtained from the National Institute of Cholera and Enteric Diseases, Calcutta, India. V. cholerae cells were grown in a gyratory shaker at $37^{\circ} \mathrm{C}$ in nutrient broth containing $0.1 \mathrm{M} \mathrm{NaCl}(\mathrm{pH}$ $8.0)$ and maintained as described previously $(12,25,35)$. E. coli cells were grown in Luria-Bertani medium with shaking at $37^{\circ} \mathrm{C}$.

Preparation of high-molecular-weight genomic DNA. Intact genomic DNA was prepared as described previously (36). V. cholerae cells in the logarithmic phase of growth were suspended in a $10 \mathrm{mM}$ Tris- $\mathrm{HCl}(\mathrm{pH} 7.6)$ buffer containing $1 \mathrm{M} \mathrm{NaCl}$. Agarose plugs were prepared by mixing equal volumes of the cell suspension and molten 1\% low-melting-point agarose (Pharmacia, Uppsala, Sweden). The plugs were suspended in lysis solution containing $6 \mathrm{mM}$ Tris- $\mathrm{HCl}$ (pH 7.5), $100 \mathrm{mM}$ EDTA, $1 \mathrm{M} \mathrm{NaCl}, 0.5 \%$ Brij $58,0.2 \%$ deoxycholate, $0.5 \%$ Sarkosyl NL-97, $1 \mathrm{mg}$ of lysozyme per $\mathrm{ml}$, and $20 \mu \mathrm{g}$ of RNase A per ml and incubated at $37^{\circ} \mathrm{C}$ for $16 \mathrm{~h}$ with gentle shaking. After the incubation period, the lysis solution was replaced by a solution containing $0.5 \mathrm{M}$ EDTA (pH 9.0), 1\% Sarkosyl, and $1 \mathrm{mg}$ of proteinase $\mathrm{K}$ per $\mathrm{ml}$, and incubation continued for $48 \mathrm{~h}$ at $50^{\circ} \mathrm{C}$, following which the plugs were stored in the same solution at $4^{\circ} \mathrm{C}$.

Restriction digestion. The restriction enzymes used were obtained from New England Biolabs. The agarose plugs containing the genomic DNA were treated with $1 \mathrm{mM}$ phenylmethylsulfonyl fluoride and washed three times for $30 \mathrm{~min}$ each in at least 10 volumes of TE (10 mM Tris- $\mathrm{HCl}$ [pH 7.5], $1 \mathrm{mM}$ EDTA). The plugs were then sliced to about 1 -mm-thick pieces. For digestion with NotI or $S$ fiI, one portion of the sliced agarose plugs was immersed into $1 \times$ buffer supplied by the manufacturer and incubated in ice for $45 \mathrm{~min}$. The buffer was then replaced by $100 \mu \mathrm{l}$ of fresh $1 \times$ buffer containing $10 \mu \mathrm{g}$ of bovine serum albumin (BSA) and $10 \mathrm{U}$ of the enzyme, and incubation continued at $37^{\circ} \mathrm{C}$ for NotI and at $50^{\circ} \mathrm{C}$ for $S f i \mathrm{I}$ for 4 to $16 \mathrm{~h}$. For partial digestion with NotI, $1 \mathrm{U}$ of the enzyme was used in the reaction mixture and incubation was for $3 \mathrm{~h}$. For CeuI digestion, five or six sliced agarose pieces were incubated in $2 \times$ buffer supplied by the manufacturer. After 15 min the buffer was replaced by $100 \mu l$ of fresh $1 \times$ buffer containing $10 \mu \mathrm{g}$ of BSA and $4 \mathrm{U}$ of the enzyme, and incubation continued at $37^{\circ} \mathrm{C}$ for $3 \mathrm{~h}$. For partial digestion with $\mathrm{CeuI}$, six agarose pieces were digested with $1 \mathrm{U}$ of the enzyme in $100 \mu \mathrm{l}$ of the reaction mixture for $2 \mathrm{~h}$ at $37^{\circ} \mathrm{C}$.

Isolation of linking clones. To isolate Not $\mathrm{I}$ linking clones of $V$. cholerae genomic DNA, the method of Zabarovsky et al. (44) was used with some modifications. About $5 \mu \mathrm{g}$ of 569B genomic DNA was digested to completion with the enzyme Sau3A, BglII, or HindIII, which cut $V$. cholerae DNA frequently. The digestion products were extracted with phenol-chloroform, ethanol precipitated, and allowed to self-ligate for $16 \mathrm{~h}$ in $1 \mathrm{ml}$ of a ligation mixture containing $2.5 \mathrm{U}$ of T4 DNA ligase. The reaction was stopped, and the DNA was precipitated and dissolved in TE ( $10 \mathrm{mM}$ Tris-HCl, $1 \mathrm{mM}$ EDTA [pH 8.0]). The self-ligated DNA was digested with $\operatorname{Not} \mathrm{I}$ and cloned into a NotI-digested, dephosphorylated pBluescript KS+/- vector (Stratagene, La Jolla, Calif.). The linking-clone libraries were maintained in E. coli JM109. Recombinant clones were isolated by bluewhite selection. Each recombinant represented a linking clone.

Preparation of probe DNA. Plasmid DNA was isolated by the rapid alkaline lysis method (10). DNA was nick translated by using $\left[\alpha-{ }^{32} \mathrm{P}\right] \mathrm{dCTP}$ (Amersham) and DNA polymerase. The reaction was carried out at $16^{\circ} \mathrm{C}$ for $1 \mathrm{~h}$, and the nick-translated labeled DNA was separated from unincorporated $\left[\alpha-{ }^{32} \mathrm{P}\right] \mathrm{dCTP}$ by passing through a Sephadex G-50 column. For labeling any particular DNA fragment, the fragment was excised from the agarose gel and labeled by random priming using the NEBlot kit (New England Biolabs).

PFGE and Southern hybridization. Electrophoresis was carried out in a Pulsaphor Plus System with a hexagonal electrode array (Pharmacia) as described previously (36). FastLane agarose (FMC, Philadelphia, Pa.) was used when DNA was to be transferred to membranes for Southern blotting, and low-melting-point agarose (Pharmacia) was used when fragments were to be recovered from gels. The enzyme-digested DNA was separated on a $1.0 \%$ agarose gel by using $20 \mathrm{mM}$ Tris-acetate ( $\mathrm{pH} 8.3)-0.5 \mathrm{mM}$ EDTA as running buffer at $10 \mathrm{~V} / \mathrm{cm}$ and various pulse times depending upon experimental conditions. Phage $\lambda$ multimeric DNA and yeast chromosomal DNA were used as molecular mass markers.

For Southern blot hybridization, the gels were stained with ethidium bromide, irradiated with UV light to nick the DNA, denatured, neutralized, and blotted to nylon membranes (27). Hybridization was carried out at $60^{\circ} \mathrm{C}$, and the filters were washed at the desired stringency. The filters were air dried and exposed to X-ray films.

Isolation, redigestion, and end labeling of DNA fragments. Restriction fragments of genomic DNA digests were excised from agarose gels under longwavelength UV light, and the agarose blocks containing DNA fragments were trimmed to about 1-mm slices and digested with a second enzyme. The doubledigested DNA was end labeled by incubating the agarose blocks in a buffer containing Klenow enzyme, $\left[\alpha-{ }^{32} \mathrm{P}\right] \mathrm{dCTP}$, and unlabeled dGTP and subjected to PFGE followed by autoradiography.

\section{RESULTS}

Restriction fragment analysis. Previous analysis of $V$. cholerae genomes using several restriction endonucleases showed
A
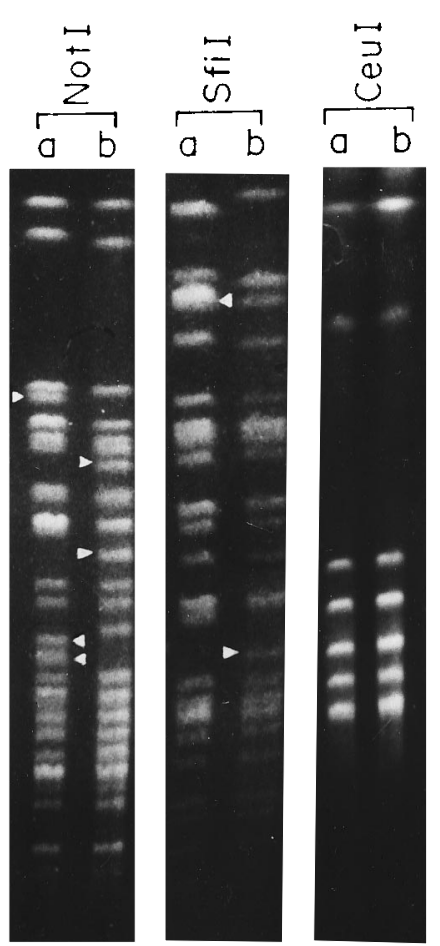

B

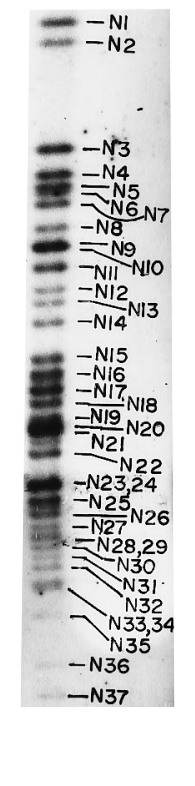

FIG. 1. (A) PFGE separation of NotI-, SfiI-, and CeuI-digested genomic DNAs of $V$. cholerae $\mathrm{O} 395$ (lanes a) and 569B (lanes b). The enzyme-digested DNA was separated on $1 \%$ FastLane agarose (FMC) with pulse time ramping between 5 and $25 \mathrm{~s}$ for $22 \mathrm{~h}$ at $10 \mathrm{~V} / \mathrm{cm}$ for NotI and SfiI. For the separation of $\mathrm{CeuI}$ fragments, pulse time was ramped from 20 to $120 \mathrm{~s}$ over $12 \mathrm{~h}$ followed by ramping from 60 to $150 \mathrm{~s}$ over $12 \mathrm{~h}$ at $10 \mathrm{~V} / \mathrm{cm}$. The gels were stained with ethidium bromide. Arrowheads, RFLP between O395 and 569B genomic DNAs. (B) Autoradiogram of PFGE-separated NotI fragments of V. cholerae 569B genomic DNA. DNAs in agarose blocks were digested with the enzyme, end labeled with $\left[\alpha-{ }^{32} \mathrm{P}\right] \mathrm{dCTP}$, and electrophoresed as described in Materials and Methods. The gel was dried and exposed to X-ray film.

that the enzymes NotI and SfiI digest the genomic DNA into a small number of large fragments that could be resolved by PFGE $(6,36)$ and that these enzymes are, therefore, the most appropriate for the construction of physical maps. Intact genomic DNAs of $V$. cholerae classical strains 569B and O395 in agarose blocks were digested with NotI, SfiI or CeuI and subjected to PFGE. The endonuclease CeuI cleaves the DNAs of a number of enteric bacteria at seven sites, and these sites are located in the $r r n$ operons (23).

The ethidium bromide-stained gels of PFGE-separated genomic DNA fragments showed that NotI digestion and SfiI digestion yielded 26 and 22 fragments, respectively, ranging from 370 to $25 \mathrm{~kb}$ for both the 569B strain and the $\mathrm{O} 395$ strain (Fig. 1A). Restriction fragments were named on the basis of the enzyme that generated the fragments (N, NotI; S, SfiI; C, $C e u \mathrm{I})$ and were numbered on the basis of size in descending order. Fragments N9 and N10, fragments N20 and N21, and fragments $\mathrm{N} 23$ and $\mathrm{N} 24$ of the genomes of the two strains are of the same size. The genome size of each of the strains, as estimated from the sizes of NotI and SfiI fragments, was about $3,200 \mathrm{~kb}$ (Table 1), which is about 0.7 times that of the $E$. coli genome. The NotI and SfiI digestion profiles of the genomes of strains 569B and O395 exhibited distinct RFLP, the polymorphism being more pronounced when the genomes were digested with the enzyme NotI (Fig. 1A, arrowheads).

The smallest fragment that could be clearly identified in stained gels was about $26 \mathrm{~kb}$. In some gels, however, faint 
TABLE 1 . Sizes of restriction fragments generated by cleavage of $V$. cholerae 569B and $\mathrm{O} 395$ chromosomes

\begin{tabular}{|c|c|c|c|c|c|}
\hline \multirow{3}{*}{ Fragment } & \multicolumn{5}{|c|}{ Size $(\mathrm{kb})^{a}$} \\
\hline & \multicolumn{2}{|c|}{ NotI } & \multicolumn{2}{|c|}{ SfiI } & \multirow{2}{*}{$\begin{array}{c}\text { CeuI } \\
(3,290)^{b}\end{array}$} \\
\hline & $\begin{array}{c}569 \mathrm{~B} \\
(3,177)\end{array}$ & $\begin{array}{c}\text { O395 } \\
(3,176)\end{array}$ & $\begin{array}{c}569 \mathrm{~B} \\
(3,077)\end{array}$ & $\begin{array}{c}\text { O395 } \\
(3,092)\end{array}$ & \\
\hline 1 & 364 & 364 & 370 & 364 & 1,420 \\
\hline 2 & 324 & 324 & 296 & 296 & 900 \\
\hline 3 & 210 & 210 & 280 & 280 & 325 \\
\hline 4 & 189 & 205 & 246 & 246 & 275 \\
\hline 5 & 180 & 189 & 210 & 210 & 180 \\
\hline 6 & 175 & 180 & 190 & 190 & 120 \\
\hline 7 & 166 & 175 & 183 & 183 & \\
\hline 8 & 150 & 150 & 175 & 175 & \\
\hline 9 & 134 & 134 & 150 & 150 & \\
\hline 10 & 134 & 134 & 140 & 140 & \\
\hline 11 & 124 & 112 & 128 & 128 & \\
\hline 12 & 112 & 106 & 109 & 109 & \\
\hline 13 & 106 & 95 & 86 & 107 & \\
\hline 14 & 96 & 85 & 83 & 83 & \\
\hline 15 & 80 & 80 & 77 & 77 & \\
\hline 16 & 74 & 74 & 73 & 73 & \\
\hline 17 & 66 & 66 & 66 & 66 & \\
\hline 18 & 62 & 62 & 58 & 58 & \\
\hline 19 & 55 & 55 & 47 & 47 & \\
\hline 20 & 49 & 49 & 44 & 44 & \\
\hline 21 & 49 & 49 & 36 & 36 & \\
\hline 22 & 42 & 42 & 30 & 30 & \\
\hline 23 & 33 & 33 & & & \\
\hline 24 & 33 & 33 & & & \\
\hline 25 & 29 & 29 & & & \\
\hline 26 & 26 & 26 & & & \\
\hline 27 & 15 & 15 & & & \\
\hline 28 & 14 & 14 & & & \\
\hline 29 & 14 & 14 & & & \\
\hline 30 & 13 & 13 & & & \\
\hline 31 & 12 & 12 & & & \\
\hline 32 & 11 & 11 & & & \\
\hline 33 & 10 & 10 & & & \\
\hline 34 & 10 & 10 & & & \\
\hline 35 & 7 & 7 & & & \\
\hline 36 & 5 & 5 & & & \\
\hline 37 & 4 & 4 & & & \\
\hline
\end{tabular}

${ }^{a}$ Totals are indicated in parentheses.

${ }^{b}$ For both $569 \mathrm{~B}$ and $\mathrm{O} 395$.

bands below $26 \mathrm{~kb}$ were frequently observed, suggesting that there might be more smaller fragments than were visible in stained gels. Identification of these smaller fragments was essential for linking the restriction fragments to construct the physical map. To identify the smaller fragments, the restriction fragments were end labeled in agarose inserts before PFGE and the autoradiograms were examined instead of stained gels. In addition to those identified in stained gels, 11 fragments of sizes ranging from 15 to $4 \mathrm{~kb}$ were detected for the Not I fragments of the $V$. cholerae 569B genome in this way (Fig. 1B).

CeuI cleavage map of the $V$. cholerae 569B and 0395 genomes. CeuI digestion of $V$. cholerae $569 \mathrm{~B}$ and $\mathrm{O} 395$ produced seven fragments ranging from 1,420 to $70 \mathrm{~kb}$ (Fig. 1A; Table 1). At a low concentration of the enzyme CeuI, partial digestion resulted in extra bands. Ten partial fragments of the CeuIdigested 569B genome (Table 2) and seven partial fragments of the $\mathrm{O} 395$ genome (data not shown) were analyzed to assemble the $C e u$ I physical maps (see Fig. 5). CeuI partial digestion fragment 1 of the $569 \mathrm{~B}$ genome is equivalent to the sum of the complete digestion fragments $\mathrm{C} 6$ and $\mathrm{C} 7$ or $\mathrm{C} 5$ and $\mathrm{C} 7$.
Partial fragment 4 was the sum of fragments C3 and C7. Partial fragment 7 provides the linkage $\mathrm{C} 3-\mathrm{C} 7-\mathrm{C} 5$. Partial fragment 2, which is the sum of the fragments $\mathrm{C} 5$ and $\mathrm{C} 6$, along with the partial fragments 3 and 6 confirmed the linkage -C3-C7-C5C6-. Partial fragment 9 showed that fragments $\mathrm{C} 1$ and $\mathrm{C} 3$ are adjacent to each other, and fragment 5 yielded the linkages between C4, C6, and C5. Partial fragments 7 and 8 established the linkages between the fragments C2, C4, C6, and C5. Partial fragment 10 can arise only from the combination of fragments $\mathrm{C} 1$ and $\mathrm{C} 2$. The linkage between the $\mathrm{CeuI}$ fragments of the genome of strain 569B is thus -C1-C3-C7-C5-C6-C4-C2-C1-, and the genome is circular (see Fig. 5). From a similar analysis of the seven partial fragments of the CeuI-digested O395 genome (data not shown), the CeuI map was constructed. The $\mathrm{CeuI}$ maps of the two classical strains are identical.

NotI cleavage map of the $V$. cholerae 569B genome. Three approaches were combined to link 37 Not I fragments of the $V$. cholerae 569B genome (see Fig. 5). These included (i) isolation of linking clones, (ii) analysis of partial digestion products, and (iii) identification of NotI fragments in CeuI and SfiI fragments using the method of fragment excision, redigestion, and end labeling.

To isolate linking clones, the genomic DNA of $V$. cholerae 569B was digested completely with the enzyme Sau3A, BglII, or HindIII, and the DNA fragments were diluted and allowed to self-ligate as described in Materials and Methods. Among the resulting circular molecules, those containing Not I sites were linearized following NotI digestion. The linear DNA fragments were cloned at the NotI site of the vector pBluescript $\mathrm{KS}+/-$. Each recombinant plasmid represents a linking clone. The three linking-clone libraries generated by digesting genomic DNA with Sau3A, BglII, and HindIII will be referred to as NLS, NLB, and NLH libraries, respectively. These libraries were screened to identify clones that linked separate NotI fragments (Table 3 ) and were used as probes in hybridization experiments with PFGE-separated chromosomal restriction fragments produced by the enzyme NotI to determine the linkages between the different fragments.

One of the major problems encountered in aligning fragments by using linking clones was in the identification of fragments based on size determination using standard molecular weight markers. This often led to erroneous conclusions, particularly for closely migrating fragments. To overcome this difficulty and to unequivocally identify fragments, instead of molecular weight markers the end-labeled fragments of the complete Not I digest of the V. cholerae 569B genome (Fig. 1B)

TABLE 2. Partial digestion products of the 569B genome generated by the enzyme CeuI

\begin{tabular}{|c|c|}
\hline $\begin{array}{l}\text { Partial } \\
\text { fragment } \\
\quad(\mathrm{kb})\end{array}$ & Possible composition $^{a}(\mathrm{~kb})$ \\
\hline \multicolumn{2}{|c|}{$1(220) \ldots \ldots \ldots \ldots . . . . . . . . . . . .64$ and C7 (190) or C5 and C7 (250) } \\
\hline \multicolumn{2}{|c|}{ 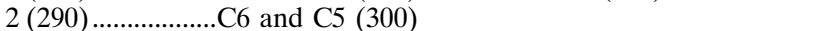 } \\
\hline \multicolumn{2}{|c|}{$3(390) \ldots \ldots \ldots \ldots . . . . . . . . . . .65$, C6, and C7 (370) or C4 and C6 (395) } \\
\hline \multicolumn{2}{|c|}{ 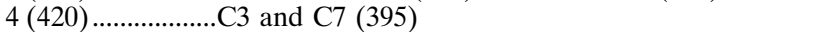 } \\
\hline \multicolumn{2}{|c|}{ 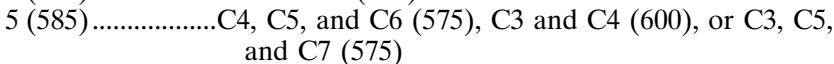 } \\
\hline $6(745) \ldots$ & ....C3, C5, C6, and C7 (695) or C3, C4, and C6 (720) \\
\hline $7(1,320)$. & $\begin{array}{l}\ldots \mathrm{C} 2, \mathrm{C} 4, \mathrm{C} 6(1,295), \text { or } \mathrm{C} 2, \mathrm{C} 5, \mathrm{C} 6 \text {, and C7 }(1,270) \text {, } \\
\text { or } \mathrm{C} 2, \mathrm{C} 4 \text {, and } \mathrm{C} 5(1,355)\end{array}$ \\
\hline $8(1,515)$. & $\ldots \mathrm{C} 2, \mathrm{C} 4, \mathrm{C} 5$, and $\mathrm{C} 6(1,475)$ \\
\hline $9(1,835)$. & $\ldots \mathrm{C} 1$ and $\mathrm{C} 3(1,745)$ \\
\hline $10(2,450)$ &. $\mathrm{C} 1$ and $\mathrm{C} 2(2,320)$ \\
\hline
\end{tabular}

${ }^{a}$ CeuI fragments. 
TABLE 3. Determination of the linkages between NotI fragments of the genome of $V$. cholerae 569B by hybridization with linking clones

\begin{tabular}{|c|c|}
\hline \multirow{2}{*}{\multicolumn{2}{|c|}{ Linking clone(s) }} \\
\hline & \\
\hline NLB 5 & N8-N4 \\
\hline NLB 29. & ..N18-N32 \\
\hline NLB $33 \ldots \ldots \ldots \ldots \ldots$ & ..N19-N21 \\
\hline NLB 39................... & ..N10-N17 \\
\hline NLB $40,92 \ldots \ldots \ldots . .$. & .. N2-N4 \\
\hline NLB 42................ & .. N8-N21 \\
\hline NLB $51 \ldots$. & N1-N22 \\
\hline NLB $53 \ldots .$. & ..N19-N28 \\
\hline NLB $130 \ldots$ & .. $\mathrm{N} 5-\mathrm{N} 27$ \\
\hline NLS 4 & N6-N26 \\
\hline NLH 1, 28, 33, 39 & ..N20-N23 \\
\hline NLH $2,44,66 \ldots \ldots$. & .. N6-N22 \\
\hline NLH $7 \ldots \ldots \ldots \ldots$ & ..N16-N34 \\
\hline NLH $8 \ldots \ldots \ldots \ldots . . . .$. & .. N5-N18 \\
\hline NLH $9,117 \ldots \ldots \ldots$ & .. N9-N25 \\
\hline NLH 19 .................... & ..N15-N26 \\
\hline NLH $20 \ldots \ldots \ldots \ldots \ldots \ldots$ & ..N11-N25 \\
\hline NLH $30 \ldots . . . .$. & .. N5-N27 \\
\hline NLH $35 \ldots \ldots \ldots \ldots \ldots \ldots$ & .. N2-N35 \\
\hline NLH 48 & ..N19-N28 \\
\hline NLH $51,123 \ldots \ldots .$. & .. N7-N15 \\
\hline NLH $102 \ldots \ldots \ldots . .$. & ..N20-N28 \\
\hline NLH $108 \ldots . .$. & ..N10-N17 \\
\hline NLH $127 .$. & .. N1-N23 \\
\hline NLH $132 \ldots \ldots \ldots \ldots . .$. & ..N14-N27 \\
\hline
\end{tabular}

were loaded in the same gel next to each lane of the NotIdigested genome that was to be probed with linking clones. This procedure allowed identification of fragments directly from the autoradiograms. Some examples of such hybridization experiments using linking clones as probes are shown in Fig. 2. The results presented in Fig. 2 clearly demonstrated that fragments $\mathrm{N} 8$ and N21, N6 and N26, N4 and N8, N20 and N28, N11 and N25, and N1 and N22 are linked. Similarly, the other linking clones provided other linkages, and more than $70 \%$ of the Not I map of the 569B genome was derived from the analysis of linking clones alone.

To determine the linkages between fragments for which linking clones were not obtained from the library search so far, individual PFGE-separated SfiI or CeuI fragments were excised from gels and digested completely with NotI and the fragments were end labeled and separated by PFGE. This allowed identification of fragments that are included in a particular SfiI or CeuI fragment. Alternatively, gel-excised SfiI or $\mathrm{CeuI}$ fragments were used as probes in Southern blot hybridization of the NotI-digested V. cholerae 569B genome. These approaches allowed the clubbing of NotI fragments that are linked (Table 4). For example, in the Southern blot hybridization experiment, the 370-kb fragment S1 hybridized with the NotI fragments N3, N11, N25, N17, N19, and N33 (Fig. 3A). When fragment S1 was digested with the enzyme NotI and end labeled, four fragments which comigrated with the NotI fragments N3, N11, N25, and N33 were produced (Fig. 3B). Thus, fragments N3, N11, N17, N19, N25, and N33 are possibly linked to each other, and in the linkage the fragments N17 and N19 might be at the two ends. The N11-N25 linkage was confirmed from linking clones (NLH 20; Table 3), and the linkage between N3 and N11 was determined from the analysis of partial fragments (Fig. 3C). Thus, the linkage N25-N11-N3 was established. The linking clones NLH 9 and NLH 117 (Table 3) showed that N25 is linked to N9. Therefore, N33
TABLE 4. Identification of NotI-digested genomic DNA fragments in isolated $S f i \mathrm{I}$ and $\mathrm{CeuI}$ restriction fragments

\begin{tabular}{|c|c|}
\hline Fragment & NotI fragment(s) \\
\hline $\mathrm{C} 1 \ldots$ & $\begin{array}{l}. . \mathrm{N} 1, \mathrm{~N} 6, \mathrm{~N} 7, \mathrm{~N} 12, \mathrm{~N} 13, \mathrm{~N} 14, \mathrm{~N} 15, \mathrm{~N} 20, \mathrm{~N} 22, \mathrm{~N} 23, \\
\mathrm{~N} 26, \mathrm{~N} 27, \mathrm{~N}^{6} 6^{a}\end{array}$ \\
\hline $\mathrm{C} 2 \ldots$. & $. \mathrm{N} 2, \mathrm{~N} 4, \mathrm{~N} 8, \mathrm{~N} 19, \mathrm{~N} 21, \mathrm{~N} 35^{a}$ \\
\hline $\mathrm{C} 3 \ldots$. & $. \mathrm{N} 10, \mathrm{~N} 18, \mathrm{~N} 24, \mathrm{~N} 32, \mathrm{~N} 37^{a}$ \\
\hline $\mathrm{C} 4 \ldots$. & $. . \mathrm{N} 9, \mathrm{~N} 16, \mathrm{~N} 25^{a}$ \\
\hline $\mathrm{C} 5 \ldots$. &..$N 3^{b}$ \\
\hline C6 .... & $. . \mathrm{N} 3, \mathrm{~N} 11^{b}$ \\
\hline S1 ..... & $. . \mathrm{N} 3, \mathrm{~N} 11, \mathrm{~N} 17, \mathrm{~N} 25, \mathrm{~N} 33^{c}$ \\
\hline $\mathrm{S} 2 \ldots .$. & $. . \mathrm{N} 5, \mathrm{~N} 13, \mathrm{~N} 14, \mathrm{~N} 27, \mathrm{~N} 36^{c}$ \\
\hline $\mathrm{S} 3 \ldots . .$. & $. . \mathrm{N} 1, \mathrm{~N} 6, \mathrm{~N} 22^{c}$ \\
\hline S5 ..... & $. . \mathrm{N} 4, \mathrm{~N}^{b}$ \\
\hline S6...... & $. . \mathrm{N} 9, \mathrm{~N} 16^{b}$ \\
\hline S8 ....... & $. . \mathrm{N} 8, \mathrm{~N} 19, \mathrm{~N} 21^{b}$ \\
\hline $\mathrm{S} 12 \ldots$ & $. . \mathrm{N} 2, \mathrm{~N} 4^{b}$ \\
\hline
\end{tabular}

${ }^{a}$ Identified by end labeling.

${ }^{b}$ Identified by hybridization.

${ }^{c}$ Identified by both end labeling and hybridization.

must be linked to N3 with $\mathrm{N} 17$ at the end. Hence, fragment S1 contained the NotI fragments linked as N25-N11-N3-N33-N17. In this particular case, in the Southern blot experiment (Fig. 3A) fragment N19 also hybridized strongly. However, neither N19-N25 nor N17-N19 linkages were obtained by any of the approaches adopted to construct the map. On the other hand, from the analysis of the linking clones it has been established that N19 is linked to N27 (Table 3, NLB 53 and NLH 48) and N21 (Table 3, NLB 33). Besides N19, several other weak signals were also observed (Fig. 3A). This was found to be true in Southern blot hybridization experiments when a number of $S$ fi I and $C e u I$ fragments were used as probes. In such cases the sum of the sizes of NotI fragments hybridized was much higher than the size of the restriction fragments used as probes. Some of the hybridization signals are presumably due to the presence of repetitive sequences in the 569B genome. This was confirmed when some linking clones were found to hybridize with more than two NotI fragments of the $V$. cholerae genome. One such NotI linking clone (NLH 115) carrying a 4.2-kb insert which hybridized with seven PFGE-separated NotI fragments of the

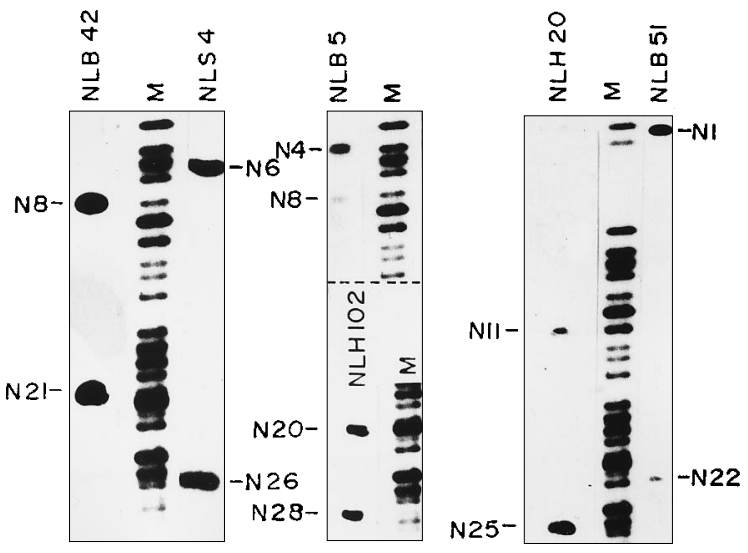

FIG. 2. Determination of linkages between NotI fragments of 569B genomic DNA using NotI linking clones as probes by Southern hybridization. Nicktranslated linking clones NLB 42, NLS 4, NLB 5, NLH 102, NLH 20, and NLB 51 were hybridized with PFGE-separated NotI fragments of the 569B genome. NotI-digested end-labeled genomic DNA was used as markers (M) for identification of linked fragments. The NotI fragments that are linked to each other are marked. 


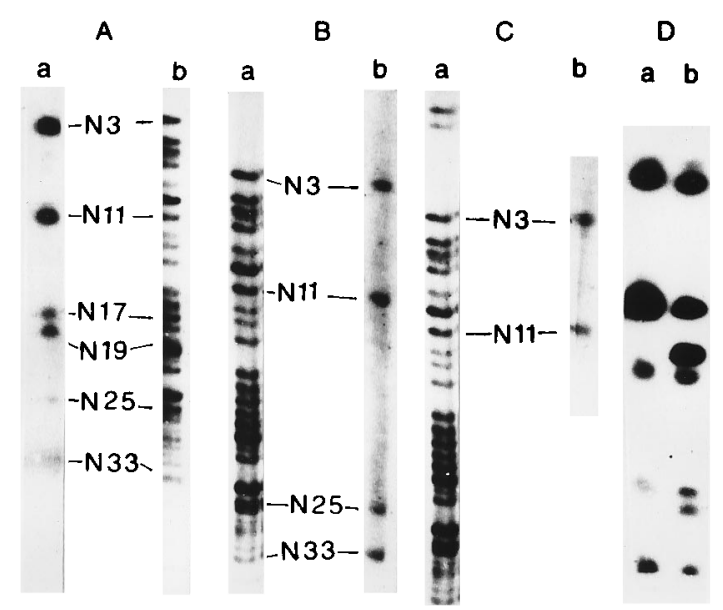

FIG. 3. (A and B) Identification of NotI fragments of the $V$. cholerae 569B genome in isolated SfiI fragments. (A) Radiolabeled fragment S1 was used as probe in Southern hybridization with the NotI-digested $V$. cholerae 569B genome (lane a). NotI-digested, end-labeled 569B genomic DNA (lane b) was used as marker for identification of linked fragments. (B) Fragment S1 was completely digested with the enzyme NotI, end labeled, and separated by PFGE (lane b). NotI-digested, end-labeled 569B genomic DNA was used as marker (lane a). (C) PFGE analysis of NotI partial digestion products. A NotI partial digestion fragment was excised from the gel, radiolabeled, and used as probe in Southern hybridization with 569B genomic DNA digested completely with NotI. The NotI fragments present in the partial digestion products are marked (lane b). Lane a, NotI-digested end-labeled 569B genomic DNA. (D) Repetitive DNA sequence in $V$. cholerae O395 (lane a) and 569B (lane b). Southern hybridization of nick-translated linking clone NLH 115 with NotI-digested genomic DNA.

569B genome and five Not I fragments of the O395 genome was identified (Fig. 3D). Identification of the repetitive DNA sequence in the $4.2-\mathrm{kb}$ insert in clone NLH 115 is in progress.

Mapping of similar-sized fragments. To determine the positions of NotI fragments N9 and N10 which appeared as a doublet, on the map, genomic DNA was digested with NotI and $S f i \mathrm{I}$ and double-digestion products were separated by PFGE. The digestion profile (Fig. 4a) revealed that one of the two fragments N9 and N10 has an SfiI site(s) and the other does not. Linking clones NLB 2, NLH 117, and NLH 108 (Table 3) showed that the doublet N9-N10 has linkages with fragments N16, N17, and N25. When these linking clones were used as probes in Southern blot hybridization of the NotI- or NotI-Sfi I-double-digested 569B genome, clone NLB 2 hybridized with the fragment in which there is no SfiI site (which will hereafter be referred to as N9) and N16 in both NotI- and NotI-SfiI-double-digested DNAs (Fig. 4b, lanes 1 and 2). Clone NLH 117 also hybridized with fragment N9 in both NotI- and NotI-SfiI-double-digested DNAs, with fragment N25 in NotIdigested DNA, and with a different fragment, $\mathrm{X}$, in the double digest (Fig. 4b, lanes 3 and 4) which appeared following digestion of N25 with SfiI. Thus, fragments N16 and N25 are linked to N9, and the linkage is -N25-N9-N16-. Clone NLH 108, on the other hand, hybridized with the N9-N10 doublet and N17 in NotI-digested DNA and with N17 and a different fragment following double digestion (data not shown). Hence, fragment N17 is linked to N10, which has an SfiI site in it.

NotI fragments N20 and N21, which are also of similar size, were resolved by digesting excised $\mathrm{CeuI}$ fragments with NotI to completion. The fragments were end labeled and separated by PFGE. One of the fragments in the N20-N21 doublet is located in fragment $\mathrm{C} 1$ (which will be referred to as N20), and the other one is located in fragment $\mathrm{C} 2$ (which will be referred to as N21). This was confirmed by Southern blot hybridization of the $C e u$ I-digested 569B genome using the linking clones NLH 39 and NLB 33 (Table 3) as probes. Clone NLB 33 hybridized to fragment $\mathrm{C} 2$, and clone NLH 39 hybridized to fragment $\mathrm{C} 1$ (data not shown). The other similar-sized fragments, N23 and N24, could not be resolved in the present study and can exchange their positions on the physical map.

Positioning of $\boldsymbol{V}$. cholerae genes on the physical map. Twenty cloned genes (Table 5) and seven rrn operons have been positioned on the physical map of the $V$. cholerae 569B genome (Fig. 5) by hybridization using homologous and heterologous probes. The gene probes used comprised DNA repair genes, heat shock protein genes, cholera toxin, and some other virulence determinant genes. The CeuI sites in the $V$. cholerae genome were taken as the positions of the $r r n$ operons in analogy with those reported for several other enteric pathogens and gram-negative bacteria (23). The genes have been positioned on the physical map on fragments they hybridized with, and the positioning does not represent the exact locations of the genes on the fragment. Genes hybridizing with the same fragment have been positioned on the fragment arbitrarily, and the positioning does not reflect the true order of the genes in the chromosome. The $c t x$ gene of $V$. cholerae mapped at two loci about $1,000 \mathrm{~kb}$ apart on the physical map. This confirms that the two copies of the Ctx genetic element are widely separated in the classical biotypes of $V$. cholerae (28). Virulence determinant genes toxR (43), tcp operon (42), and the Ctx genetic elements (32) comprising zot, cep, ace, and ctx $A B$ genes are widely separated on the physical map. From the limited number of genes positioned on the physical map, it

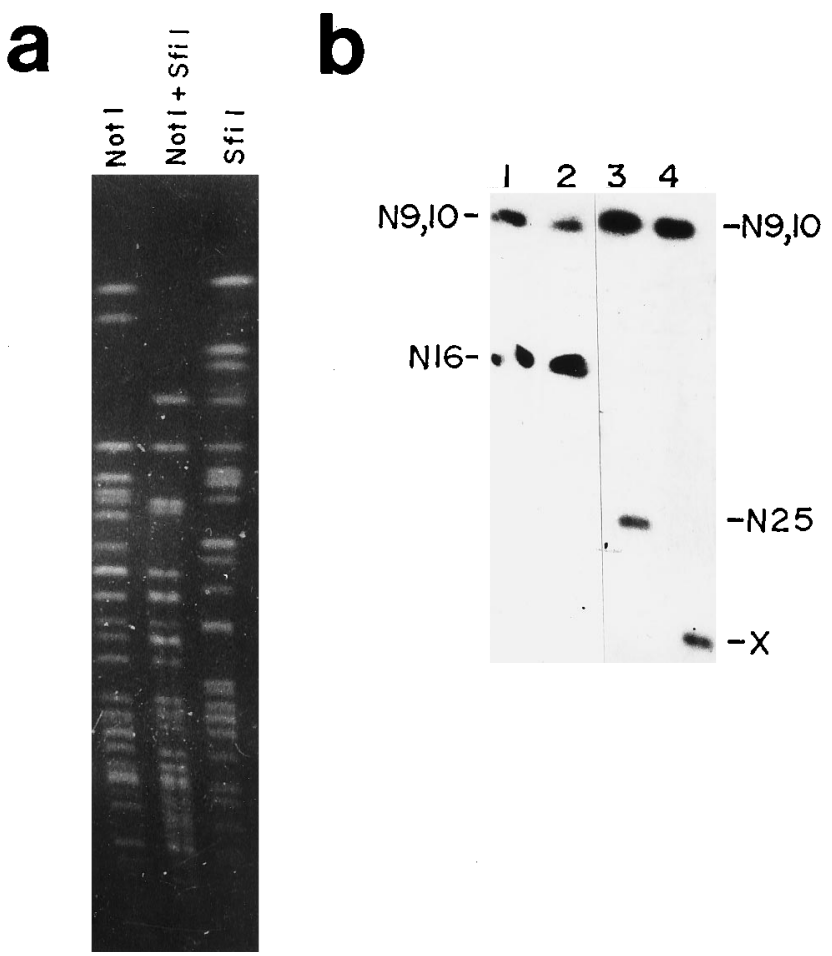

FIG. 4. (a) PFGE separation of $V$. cholerae 569B genomic DNA digested with NotI, SfiI and NotI, or SfiI. Electrophoresis was performed as described in the legend to Fig. 1A. (b) Determination of NotI fragments linked to N9 and N10 by Southern hybridization of NotI and SfiI double-digested 569B genomic DNA using nick-translated linking clones NLB 2 (lanes 1 and 2) and NLH 117 (lanes

3 and 4 ) as probes. Lanes 1 and 3, NotI-digested 569B genomic DNA; lanes 2 and 4, NotI- and SfiI-digested 569B genomic DNA. X, fragment derived from N25 following double digestion. 
TABLE 5. Probes used for localizing genes on the physical map of the genome of $V$. cholerae 569B

\begin{tabular}{|c|c|c|c|c|c|}
\hline \multirow{2}{*}{ Probe } & \multirow{2}{*}{ Gene } & \multirow{2}{*}{ Source } & \multicolumn{2}{|c|}{ Fragment hybridized } & \multirow{2}{*}{ Reference } \\
\hline & & & Not I & $C e u \mathrm{I}$ & \\
\hline pCVD15 & $\operatorname{ctx}$ (cholera toxin) & V. cholerae & $\mathrm{N} 4, \mathrm{~N} 15$ & $\mathrm{C} 1, \mathrm{C} 2$ & 19 \\
\hline pJT470 & mutS (DNA mismatch repair) & V. cholerae & N15 & $\mathrm{C} 1$ & 5 \\
\hline PJT250 & mutL (DNA mismatch repair) & V. cholerae & N11 & C6 & 5 \\
\hline pJA360 & mutU (DNA mismatch repair) & V. cholerae & N13 & $\mathrm{C} 1$ & \\
\hline pRB101 & dam (adenine methylase) & V. cholerae & N9 & $\mathrm{C} 4$ & 3 \\
\hline pDCM1 & $v s r$ (short-patch DNA repair) & E. coli & N7 & $\mathrm{C} 1$ & 8 \\
\hline pSB180 & sulA (cell division inhibitor) & $V$. cholerae & $\mathrm{N} 21$ & $\mathrm{C} 1$ & 11 \\
\hline pSB180 & $c d p$ (concatemer destabilizer) & V. cholerae & $\mathrm{N} 21$ & $\mathrm{C} 1$ & 11 \\
\hline pKV7 & $r p o H\left(\right.$ gene for $\left.\sigma^{32}\right)$ & E. coli & N11 & C6 & 45 \\
\hline pOF12 & groEL (gene for Hsp60) & E. coli & N9 & $\mathrm{C} 4$ & 16 \\
\hline pKP31 & dnaK (gene for Hsp70) & E. coli & $\mathrm{N} 22$ & $\mathrm{C} 1$ & 4 \\
\hline pKY3 & $\sec Y$ (protein translocation) & E. coli & N9 & $\mathrm{C} 4$ & 37 \\
\hline Oligomer $^{a}$ & toxR (virulence gene activator) & V. cholerae & N16 & $\mathrm{C} 4$ & 43 \\
\hline PCR probe p $^{b}$ & $t c p$ (toxin-coregulated pilus) & V. cholerae & N14 & $\mathrm{C} 1$ & $20 \mathrm{a}$ \\
\hline
\end{tabular}

${ }^{a} 5^{\prime}$-CGGGATCCTACTCACACACTTTGATGGC-3'.

${ }^{b} V$. cholerae classical specific primer sequences 5'-CACGATAAGAAAACCGGTCAAGAG-3' and 5'-ACCAAATGCAACGCCGAATGGAGC-3'. The amplicon size was $618 \mathrm{bp}$.

appears that there are regions on the $V$. cholerae genome with high gene density. Of the 27 genes positioned, 11 are clustered within a 500-kb (N16-N9-N25-N11-N3; Fig. 5) region.

\section{DISCUSSION}

A physical map of the $V$. cholerae 569B genome has been constructed by using PFGE and hybridization techniques, and 26 homologous and heterologous genes and operons were assigned to the physical map. To our knowledge, this is the first combined physical and genetic map of the genome of $V$. cholerae, an organism for which a genetic map is not available. The genomes of strains 569B and O395 are circular, and the size has been estimated to be $3,200 \mathrm{~kb}$, which is about $70 \%$ of the

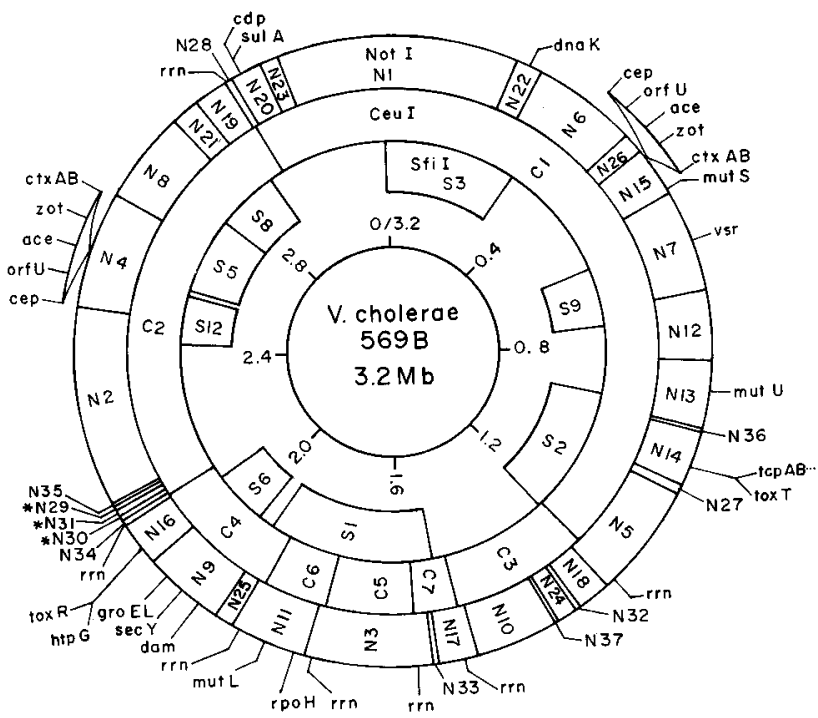

FIG. 5. Physical and genetic mapping of the $V$. cholerae 569B genome using the enzymes NotI, CeuI, and SfiI. The SfiI map is not complete. Restriction fragments are numbered on the basis of size (Table 1).*, tentative assignment. The genetic markers are described in Table 5. The position of the genetic marker in a particular fragment is arbitrary, and the positions of the markers in a single fragment do not reflect their true order in the chromosome. CeuI sites were taken as the positions of the $r r n$ operons. The innermost circle represents the scale in megabases. size of the E. coli (40) and Salmonella typhimurium (24) genomes. The genome sizes of a majority of human pathogens range between 1.6 and $2.6 \mathrm{Mb}(21)$. These organisms are metabolically less active than $E$. coli. The genome size of classical $V$. cholerae is close to that of Yersinia pestis $(3.5 \mathrm{Mb})(26)$, and these organisms can be grown in defined media similarly to $E$. coli. The genome size of the biotype El Tor of $V$. cholerae is about $2.5 \mathrm{Mb}(36)$, and these cells are also metabolically active. Thus, the genes controlling the vital metabolic functions are present in $V$. cholerae cells in spite of their genomes being significantly smaller than that of $E$. coli.

A total of 59 restriction sites were mapped by using three restriction endonucleases and by combining results obtained from three different experimental approaches. Linking clones were used to determine the proximity of neighboring PFGE fragments. The linking-clone data were combined with the second method, fragment hybridization, which was used to determine overlapping fragments. CeuI- and SfiI-generated fragments were either hybridized to NotI-digested DNA filters or digested completely with NotI and end labeled (Table 4). The third method used was analysis of partially digested DNA fragments. The CeuI digestion fragments of the genomes of strains 569B and O395 were assembled from the analysis of partial digestion fragments alone. The CeuI maps of strains 569B and $\mathrm{O} 395$ are identical. The NotI and SfiI digestion patterns of the genomes of these two strains, however, showed distinct RFLP (Fig. 1A). The enzyme CeuI has seven sites in the genomes of 569B and O395, as reported for E. coli, S. typhimurium, and several other gram-negative bacteria (23). This enzyme cleaves DNA at no sites other than the $r r n$ operons. Thus, it appears that $V$. cholerae also has seven rrn operons. This supports the hypothesis that the locations and number of $r r n$ operons in gram-negative bacteria are conserved. $V$. cholerae genes dam, rpoH, mutL, and groEL are located close to $r r n$ operons as in E. coli (2), suggesting that the organization of genes in the neighborhood of $r r n$ loci might be maintained in different gram-negative organisms.

Linking clones have been used so far to construct physical maps of Rhodobacter sphaeroides (41), a Synehococcus sp. (13), and Neisseria gonorrhoeae (14). The modified method of constructing linking-clone libraries described in the present report is perhaps the simplest among the existing methods and also allows isolation of a large number of linking clones from a 
single experiment. This method is a modification of the approach used to generate a human chromosome 3-specific NotI linking-clone library (44). More than $70 \%$ of the NotI fragments of the $V$. cholerae 569B genome were linked by using linking clones alone. The linking-clone libraries generated during the present study can be used to examine the chromosomal organization of the biotype El Tor and the current epidemic strain $V$. cholerae $\mathrm{O} 139$ Bengal, the genome sizes of which are 500 to $600 \mathrm{~kb}$ smaller than those of classical strains $(6,36)$. It appears that the 500- to $600-\mathrm{kb}$ genomic DNA missing in the El Tor biotype is not essential for maintaining the pathogenic and epidemic potentials of this organism, since the strains belonging to the El Tor biotype are as virulent as the classical ones. The linking-clone libraries will be useful for identifying the DNA that is present in the chromosomes of classical strains but absent in the El Tor and O139 strains and in searching for new genes in $V$. cholerae.

Strain 569B is considered unusual from the point of view of regulation of virulence determinants, since this strain is independent of ToxR and ToxS for the expression of the ToxR regulon unlike other toxinogenic $V$. cholerae strains, such as strain O395, in which ToxR controls the virulence regulon (15). It is also assumed that this strain undergoes rapid genetic variation under laboratory conditions. However, in the course of our studies on the construction of the physical map of this strain during the last several years we have never detected any RFLP in the NotI or SfiI restriction fragments of the genome of strain 569B.

A number of homologous and heterologous genes have been positioned on the physical map of the $V$. cholerae genome, and with the addition of more genes the utility of the map will be expanded and its resolution will improve. This will lead to more insights into chromosome organization, the mechanisms of gene regulation, and the molecular basis of pathogenicity of this important human enteric pathogen.

\section{ACKNOWLEDGMENTS}

RM and SS have contributed equally to this study.

We thank A. C. Ghosh, Department of Microbiology, Bose Institute, Calcutta, India, for providing toxR. We are grateful to all members of the Biophysics Division for their kind cooperation and encouragement during the study.

R.M. is grateful to the Council of Scientific and Industrial Research, New Delhi, India, for a predoctoral fellowship. This work was supported by the Department of Biotechnology [grants BT/TF/15/03/91 and $\mathrm{BT} / \mathrm{MB} / 05 / 012 / 94]$ of the government of India.

\section{REFERENCES}

1. Albert, M. J., A. K. Siddique, M. S. Islam, A. S. J. Faruque, M. Ansaruzzaman, S. M. Faruque, and R. B. Sack. 1993. Large outbreak of clinical cholera due to Vibrio cholerae non-O1 in Bangladesh. Lancet 341:704.

2. Bachmann, B. J. 1990. Linkage map of Escherichia coli K-12, edition 8. Microbiol. Rev. 54:130-197.

3. Bandyopadhyay, R., and J. Das. 1994. DNA adenine methyl-transferase encoding gene (dam) of Vibrio cholerae. Gene 140:67-71.

4. Bardwell, J. C. A., and E. A. Craig. 1984. Major heat shock gene of Drosophila and the Escherichia coli heat-inducible dna $\mathrm{K}$ gene are homologous. Proc. Natl. Acad. Sci. USA 81:848-852.

5. Bera, T. K., S. K. Ghosh, and J. Das. 1989. Cloning and characterization of the $m u t \mathrm{~L}$ and $m u t \mathrm{~S}$ genes of Vibrio cholerae: nucleotide sequence of the $m u t \mathrm{~L}$ gene. Nucleic Acids Res. 17:6241-6251.

6. Bhadra, R. K., S. Roychoudhury, R. K. Banerjee, S. Kar, R. Majumdar, S. Sengupta, S. Chatterjee, G. Khetawat, and J. Das. 1995. Cholera toxin (CTX) genetic element in Vibrio cholerae O139. Microbiology 141:1977-1983.

7. Bhadra, R. K., S. Roychoudhury, and J. Das. 1994. Vibrio cholerae O139 El Tor biotype. Lancet 343:728.

8. Bhagwat, A. S., A. Sohail, and R. J. Roberts. 1986. Cloning and characterization of the $\mathrm{dcm}$ locus of Escherichia coli K-12. J. Bacteriol. 166:751-755.

9. Bhaskaran, K., V. B. Sinha, and S. S. Iyer. 1973. Chromosome mobilization in Vibrio cholerae (biotype El Tor) mediated by sex factor P. J. Gen. Microbiol. 78:119-124.
10. Birnboim, H. C., and J. Doly. 1979. A rapid alkaline extraction procedure for screening recombinant plasmid DNA. Nucleic Acids Res. 7:1513-1526.

11. Biswas, S. K., R. Chowdhury, and J. Das. 1992. A 14-kilodalton inner membrane protein of Vibrio cholerae biotype El Tor confers resistance to group IV choleraphage infection to classical vibrios. J. Bacteriol. 174:62216229.

12. Chaudhuri, K., R. K. Bhadra, and J. Das. 1992. Cell surface characteristics of environmental and clinical isolates of Vibrio cholerae non-O1. Appl. Environ. Microbiol. 58:3567-3573.

13. Chen, X., and W. R. Widger. 1993. Physical genome map of the unicellular cyanobacterium Synechococcus sp. strain PCC 7002. J. Bacteriol. 175:51065116 .

14. Dempsey, J. A. F., W. Litaker, A. Madhure, T. L. Snodgrass, and J. G. Cannon. 1991. Physical map of the chromosome of Neisseria gonorrhoeae FA1090 with locations of genetic markers including opa and pil genes. J. Bacteriol. 173:5476-5486.

15. DiRita, V. J. 1992. Co-ordinate expression of virulence genes by ToxR in Vibrio cholerae. Mol. Microbiol. 6:451-458.

16. Fayet, O., T. Ziegelhoffer, and C. Georgopoulos. 1989. The groES and groEL heat shock gene products of Escherichia coli are essential for bacterial growth at all temperatures. J. Bacteriol. 171:1379-1385.

17. Finkelstein, R. A. 1973. Cholera. Crit. Rev. Microbiol. 2:553-623.

18. Heselkorn, R. 1989. Excision of elements interrupting nitrogen fixation operons in cyanobacteria, p. 735-742. In D. E. Berg and M. M. Howe (ed.), Mobile DNA. American Society for Microbiology, Washington, D.C.

19. Kaper, J. B., H. Lockman, M. M. Baldini, and M. M. Levine. 1984. A recombinant live oral cholera vaccine. Bio/Technology 2:345-349.

20. Kaper, J. B., J. G. Morris, and M. M. Levine. 1995. Cholera. Clin. Microbiol Rev. 8:48-86.

20a.Keasler, S. P., and R. H. Hall. 1993. Detecting and biotyping Vibrio cholerae O1 with multiplex polymerase chain reaction. Lancet 341:1661.

21. Krawiec, S., and M. Riley. 1990. Organization of the bacterial genome. Microbiol. Rev. 54:502-539.

22. Kuempel, P. L., A. J. Plletier, and T. M. Hill. 1990. tus and the terminators: inhibition of replication in Escherichia coli, p. 297-306. In K. Drlica and M. Riley (ed.), The bacterial chromosome. American Society for Microbiology, Washington, D.C

23. Liu, S.-L., A. Hessel, and K. E. Sanderson. 1993. Genomic mapping with I-CeuI, an intron-encoded endonuclease specific for genes for ribosomal RNA in Salmonella spp., Escherichia coli, and other bacteria. Proc. Natl. Acad. Sci. USA 90:6874-6878.

24. Liu, S.-L., and K. E. Sanderson. 1992. A physical map of the Salmonella typhimurium LT2 genome made by using XbaI analysis. J. Bacteriol. 174: 1662-1672.

25. Lohia, A., S. Majumdar, A. N. Chatterjee, and J. Das. 1985. Effect of changes in the osmolarity of the growth medium on Vibrio cholerae cells. J. Bacteriol. 163: $1158-1166$

26. Lucier, T. S., and R. R. Brubaker. 1992. Determination of genome size, macrorestriction pattern polymorphism, and nonpigmentation-specific deletion in Yersinia pestis by pulsed-field gel electrophoresis. J. Bacteriol. 174: 2078-2086.

27. Maniatis, T., E. F. Fritsch, and J. Sambrook. 1982. Molecular cloning: a laboratory manual. Cold Spring Harbor Laboratory, Cold Spring Harbor, N.Y.

28. Mekalanos, J. J. 1983. Duplication and amplification of toxin genes in Vibrio cholerae. Cell 35:253-263.

29. Morris, J. G. 1990. Non-O group I Vibrio cholerae: a look at the epidemiology of an occasional pathogen. Epidemiol. Rev. 12:179-191.

30. Panda, D. K., U. Dasgupta, and J. Das. 1991. Transformation in Vibrio cholerae by plasmid DNA. Gene 105:107-111.

31. Parker, C., D. Gauthier, A. Tate, K. Richardson, and W. R. Romig. 1979. Expanded linkage map of Vibrio cholerae. Genetics 91:191-214.

32. Pearson, G. D. N., A. Woods, S. L. Chiang, and J. J. Mekalanos. 1993. CTX genetic element encodes a site-specific recombination system and an intestinal colonization factor. Proc. Natl. Acad. Sci. USA 90:3750-3754.

33. Ramamurthy, T., S. Garg, R. Sharma, S. K. Bhattacharya, G. B. Nair, T. Shimada, T. Takeda, T. Karasawa, H. Kurazano, A. Pal, and Y. Takeda. 1993. Emergence of novel strain of Vibrio cholerae with epidemic potential in southern and eastern India. Lancet 341:703-704.

34. Riley, M., and K. E. Sanderson. 1990. Comparative genetics of Escherichia coli and Salmonella typhimurium, p. 85-95. In K. Drlica and M. Riley (ed.), The bacterial chromosome. American Society for Microbiology, Washington, D.C.

35. Roy, N. K., G. Das, T. S. Balganesh, S. N. Dey, R. K. Ghosh, and J. Das. 1982. Enterotoxin, DNA repair and alkaline phosphatase of Vibrio cholerae before and after animal passage. J. Gen. Microbiol. 128:1927-1932.

36. Roychoudhury, S., R. K. Bhadra, and J. Das. 1994. Genome size and restriction fragment length polymorphism analysis of Vibrio cholerae strains belonging to different serovars and biotypes. FEMS Microbiol. Lett. 115: 329-334.

37. Shiba, K., K. Ito, T. Yura, and D. P. Cerretti. 1984. A defined mutation in the protein export gene within the $s p c$ ribosomal protein operon of Escherichia 
coli: isolation and characterization of a new temperature sensitive $\sec \mathrm{Y}$ mutant. EMBO J. 3:631-635.

38. Shimada, T., E. Arakawa, K. Itoh, T. Okitsu, A. Matsushima, Y. Asai, S. Yamai, T. Nakazato, G. B. Nair, M. J. Albert, and Y. Takeda. 1994. Extended serotyping scheme for Vibrio cholerae. Curr. Microbiol. 28:175-178.

39. Smith, C. L., and C. R. Cantor. 1987. Purification, specific fragmentation and separation of large DNA molecules. Methods Enzymol. 155:449-467.

40. Smith, C. L., J. G. Econome, A. Schutt, S. Klco, and C. R. Cantor. 1987. A physical map of the Escherichia coli K12 genome. Science 236:14481453.

41. Suwanto, A., and S. Kaplan. 1989. Physical and genetic mapping of the Rhodobacter sphaeroids 2.4 .1 genome: presence of two unique circular chromosomes. J. Bacteriol. 171:5850-5859.
42. Taylor, R. K., V. L. Miller, D. B. Furlong, and J. J. Mekalanos. 1987. The use of phoA gene fusions to identify a pilus colonization factor coordinately regulated with cholera toxin. Proc. Natl. Acad. Sci. USA 84:2833-2837.

43. Waldor, M., and J. J. Mekalanos. 1994. ToxR regulates virulence gene expression in non-O1 strains of Vibrio cholerae that cause epidemic cholera. Infect. Immun. 62:72-78.

44. Zabarovsky, E. R., F. Boldog, T. Thompson, D. Scanlon, G. Winberg, Z. Marcsek, R. Erlandsson, E. J. Stanbridge, G. Klein, and J. Sumegi. 1990. Construction of human chromosome 3 specific NotI linking library using a novel cloning procedure. Nucleic Acids Res. 18:6319-6324.

45. Zhou, Y.-N., N. Kusukawa, J. W. Erickson, C. A. Gross, and T. Yura. 1988 Isolation and characterization of Escherichia coli mutants that lack the heat shock sigma factor $\sigma^{32}$. J. Bacteriol. 170:3640-3649. 